\title{
Neoplastic Plasma Cells 10-60 Percent of Bone Marrow Nucleated Cells
}

National Cancer Institute

\section{Source}

National Cancer Institute. Neoplastic Plasma Cells 10-60 Percent of Bone Marrow

Nucleated Cells. NCI Thesaurus. Code C150711.

A semi-quantitative microscopic finding indicating that between 10 and 60 percent of the nucleated cells in a bone marrow sample are neoplastic plasma cells. 